\title{
Simulation of human-machine interaction in an automotive manufacturing cell using Digital Factory (DF)
}

\author{
Guilherme Canuto da Silva ${ }^{a}$ Leonardo Morais de Souza ${ }^{b}$ Paulo Carlos Kaminski ${ }^{b}$ \\ Universidade Federal do ABC \\ buniversidade de São Paulo \\ e-mails: guilherme.canuto@ufabc.edu.br; leonardo.morais.souza@usp.br; pckamins@usp.br
}

\begin{abstract}
Digital Factory (DF) is defined as a set of production process development-oriented softwares, involving from the planning through the implementation of such processes. This work presents the application of DF tools in the study of man-machine interaction in a manufacturing process. Therefore, first, a theoretical background on the subject and then a case study of the assembly process in a European automaker in Brazil are developed. Finally, the adherence of the model to the real situation is evaluated. Results and suggestions for a future work are presented and the work is concluded with pertinent considerations.
\end{abstract}

Keywords: Digital Factory (DF), software, carmaker, automotive manufacturing.

\section{Introduction}

Product Development Process (PDP) can be defined as a set of activities organized in macro-phases and phases sequentially disposed comprising product concept, development of the product and manufacturing process, production and product distribution in the market. Systems supporting PDP activities use virtual and physical systems. Digital Factory is among the virtual systems (KÜHN, 2006; SILVA, 2013).

The concept Digital Factory (DF) offers an integrated approach to improve the processes of product and manufacturing process engineering. DF can be defined as the generic term for a network that comprises digital models, methods and tools - including 3D simulation and visualization - integrated by a continuous system of data management. Its purpose is to integrally plan, evaluate and continuously improve all main structures, processes and resources of the real factory, together with the product (POLÁŠEK; BUREŠ́ ŠIMON, 2015). Its initial focus is on the planning of production and factory design, coordinated with all corporative processes (KÜHN, 2006; VEREIN DEUTSCHER INGENIEURE, 2008).

DF's vision focus on the integration in different levels of methods and tools available to plan and test the product, related manufacturing and operational control of the plant. Thus, it integrates the following PDP stages: product design/development, test and optimization, manufacturing design/development, process optimization, manufacturing process implementation, and planning and control of manufacturing operation (KÜHN, 2006; SILVA, 2013).

This work aims to present the use of DF tools in the production process development, mainly addressing the study of man-machine interaction.

This study is divided in 5 sections. Introduction and structure of the article are in Section 1. Section 2 presents a theoretical background on the subject. A case study is presented in Section 3 and its results analysis is presented in Section 4. In Section 5, suggestions for a future work are identified and presented and the work is concluded with considerations pertinent to the subject.

\section{Theoretical background}

The theoretical background developed by Bracht, Geckler and Wenzel (2011) and updated by Silva and Kaminski (2015) has been complemented and categorized to evaluate the scientific production on the subject and the current DF applications in production process development. The search was performed mainly in publications between 2001 and 2016. The articles were tabulated and summarized according to their main information. The articles were also classified as part of Product Development Process (PDP) and Digital Factory (DF), according to the application fields: product design/development, process design/development, process implementation, plant operation, DF concept/theory. Search result, summary and classification of theoretical background can be seen in Table 1 . 
Table 1. FD articles classified and their summaries (updated, complemented and categorized from Bracht, Geckler and Wenzel (2011); Silva and Kaminski (2015)).

\begin{tabular}{|c|c|c|c|}
\hline Author & Main subject & Classification & Year \\
\hline Bley and Franke* & $\begin{array}{l}\text { Models management } \\
\text { Exchange of information } \\
\text { Knowledge management }\end{array}$ & Process design/development & 2001 \\
\hline Dombrowiski et al.* & $\begin{array}{l}\text { Virtual model of the real plant to be used } \\
\text { Mapping of all project resources } \\
\text { Computer-aided factory processes }\end{array}$ & $\begin{array}{l}\text { DF concept/theory and } \\
\text { Process design/development }\end{array}$ & 2001 \\
\hline Bracht* & $\begin{array}{l}\text { Link between product development and production } \\
\text { planning }\end{array}$ & $\begin{array}{l}\text { DF concept/theory and } \\
\text { Process design/development }\end{array}$ & 2002 \\
\hline Wiedahl* & Computational model & $\begin{array}{l}\text { DF concept/theory and } \\
\text { Process design/development }\end{array}$ & 2002 \\
\hline Westkämper et al.* & Information model & DF concept/theory & 2003 \\
\hline Wenzel et al. * & $\begin{array}{l}\text { Digital models connected to the network } \\
\text { Methods and tools }\end{array}$ & $\begin{array}{l}\text { DF concept/theory and } \\
\text { Process design/development }\end{array}$ & 2003 \\
\hline Maropoulos & Digital enterprise technology (DET) & $\begin{array}{l}\text { DF concept/theory and } \\
\text { Process design/development }\end{array}$ & 2003 \\
\hline Marczinski* & Computer-aided engineering tools & Process design/development & 2006 \\
\hline $\begin{array}{l}\text { Verein Deutscher } \\
\text { Ingenieure }\end{array}$ & Guidelines and foundations & DF concept/theory & 2008 \\
\hline Kim et al. & Assistant to digital factory & DF concept/theory & 2010 \\
\hline $\begin{array}{l}\text { Américo and } \\
\text { António }\end{array}$ & Models of factories & Process design/development & 2011 \\
\hline $\begin{array}{l}\text { Silva, Kaminski } \\
\text { and Gruber }\end{array}$ & Investigation of available DF resources in the analysis of workforce & Process design/development & 2014 \\
\hline Büttner & Development and expansion of DF concept towards Industrie 4.0 & Plant operation & 2014 \\
\hline Silva and Kaminski & Digital factory concepts manufacturing cells design & Process design/development & 2015 \\
\hline \begin{tabular}{l|l} 
Krückhans and \\
Meier
\end{tabular} & $\begin{array}{l}\text { Communications between real and virtual DF components in a plant } \\
\text { structure }\end{array}$ & $\begin{array}{l}\text { Process design/development } \\
\text { and factory operation }\end{array}$ & 2015 \\
\hline Choi, Kim and Noh & Planning, design and application strategy of DF in real industries & $\begin{array}{l}\text { DF concept/theory and } \\
\text { Process design/development }\end{array}$ & 2015 \\
\hline $\begin{array}{l}\text { Husár and } \\
\text { Dupláková }\end{array}$ & Use of DF in logistic planning & Process design/development & 2015 \\
\hline Or and Zou & Tools and aplications of DF & $\begin{array}{l}\text { DF concept/theory and } \\
\text { process implementation }\end{array}$ & 2015 \\
\hline $\begin{array}{l}\text { Polásek, Bures and } \\
\text { Simon }\end{array}$ & Comparision between ergonomie softwares & $\begin{array}{l}\text { DF concept/theory and } \\
\text { Process design/development }\end{array}$ & 2015 \\
\hline $\begin{array}{l}\text { Toro, Barandiarana } \\
\text { and Posadaa }\end{array}$ & Implementation of Systems of Intelligence in Industry 4.0 & $\begin{array}{l}\text { Process design/development } \\
\text { and process implementation }\end{array}$ & 2015 \\
\hline $\begin{array}{l}\text { Harrison, Vera and } \\
\text { Ahmad }\end{array}$ & Analysis of methods of use of Cyber-Physical Systems & Process design/development & 2016 \\
\hline Cherubini et al. & Human-machine cooperation in the manufacturing process & Process design/development & 2016 \\
\hline
\end{tabular}

*apud Bracht, Geckler and Wenzel (2011).

\section{Case study}

Proposed case study is based on a real automotive manufacturing cell of an European automaker branch installed in Brazil. The studied case concerns the assembly cell of the turn signal switch set, where a single worker is responsible for assembling different types, according to the car models manufactured by the automaker. Figure 1 shows the manufacturing cell addressed in the case study.

Table 2 shows a list of components used in the assembly of turn signal switch set, and the corresponding storage position in the manufacturing cell.
Real cell layout, parts distribution, worker's working way and assembly sequence were considered to evaluate man-machine interaction. All these factors allowed to adjust the model to the real case.

Tecnomatix Plant Simulation v.11 (SIEMENS, 2016) was used for model development. This software allows modeling, simulation and validation of discrete systems. Figure 2 shows an abstract model containing the main elements used in the modeling of manufacturing cell.

Detailed model simulates two main parts of the task: path performed by the worker during parts selection and 
Table 2. Components of turn signal switch set and storage position.

\begin{tabular}{|c|c|}
\hline Storage position & Components \\
\hline 1 & Lining \\
\hline 2 & Lower Cover \\
\hline 3 & Upper Cover \\
\hline 4 & Steering Column \\
\hline 5 & Switch \\
\hline 6 & Box Panel \\
\hline 7 & Storage Compartment \\
\hline 8 & Lining \\
\hline 9 & Mount \\
\hline 10 & Fuse \\
\hline 11 & Clamp \\
\hline 12 & Bolt \\
\hline 13 & Assembly station \\
\hline
\end{tabular}

assembly sequence of turn signal switch set. Table 3 shows the model elements and theirs functions.

Table 4 shows the automaker's main parameters used in modeling the case study.

The following restrictions were imposed to the model:

- Assembly of only one model of turn signal switch set (therefore, only one assembly routine of the worker was represented);

- Minimum shift change time (thus, shift change time has no influence on the production time).

The same manufacturing cell design presented in Figure 1 was used as basis to develop the model and determine parts positioning. Therefore, the entities and
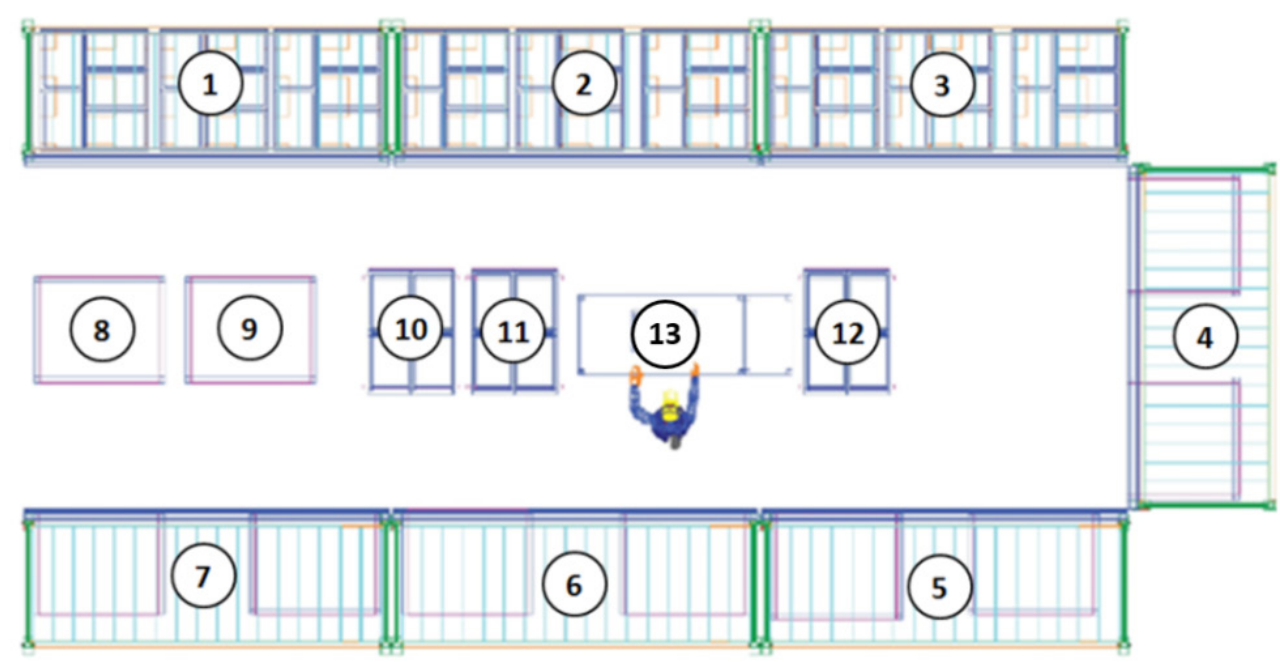

Figure 1. Manufacturing cell (adapted from SILVA and KAMINSKI, 2015).

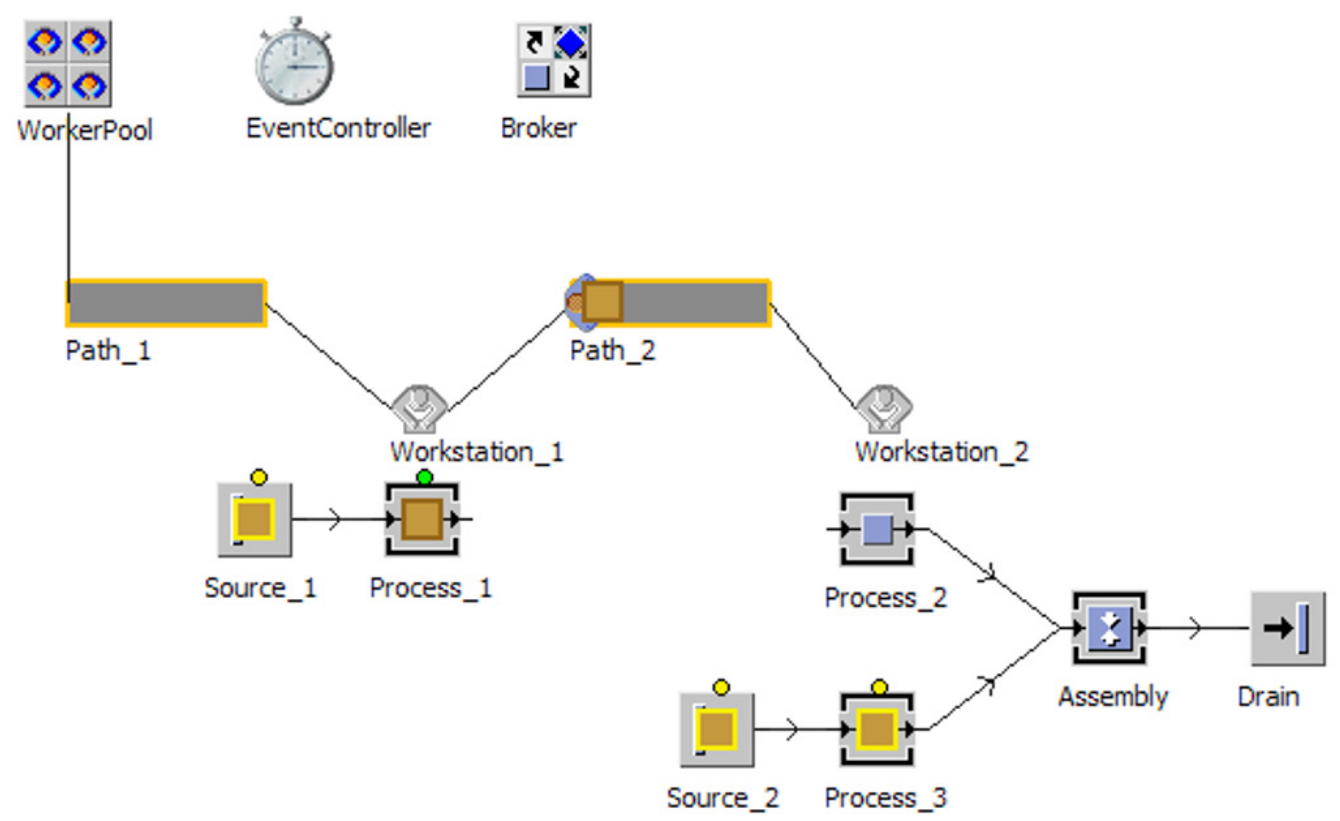

Figure 2. Detailed model developed using Tecnomatix Plant Simulation. 
(1)

(2)

(3)
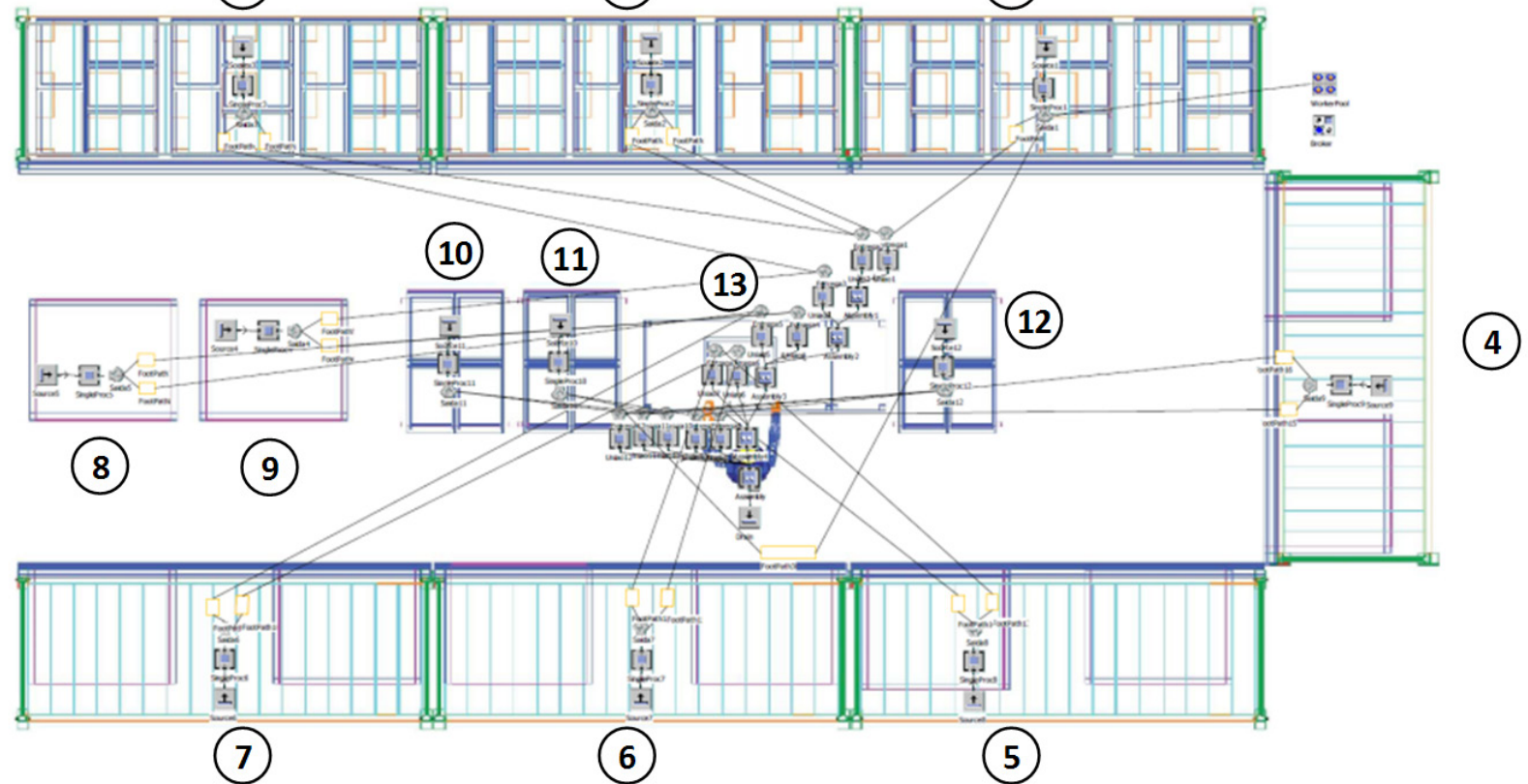

Figure 3. Model developed using Plant Simulation.

Table 3. Model elements and theirs functions (adapted from SIEMENS, 2016).

\begin{tabular}{|l|l|l|}
\hline & Same & \\
\hline
\end{tabular}


their respective parameters were placed obeying the same configuration of the physical cell. Figure 3 shows the model developed. The elements used in the modeling are presented and explained in Table 5.

Table 4. Case study parameters.

\begin{tabular}{|l|c|}
\hline \multicolumn{1}{|c|}{ Parameters } & Values \\
\hline Production volume & 950 cars \\
\hline Mean distances covered & 1.2 meters \\
\hline Operator efficiency & $90 \%$ \\
\hline Operator's footpath speed & $1.67 \mathrm{~m} / \mathrm{s}$. \\
\hline Time of operation cycle & 1 minute \\
\hline Work hours & 24 hours. \\
\hline
\end{tabular}

After finishing the model, the compatibility of results provided by the model was analyzed, compared to the automaker's real production values.

\section{Results analysis}

Using parameters of Table 4, the model provided a result of 959 sets produced in 24 hours. The result is very close to the expected production (950 sets per day). Moreover, the difference between expected value and resulting value can be justified by the restrictions proposed initially. The statistics results for an 8-hour operation shift are showed in Tables 6 and 7.

Table 5. Elements used in the modeling.

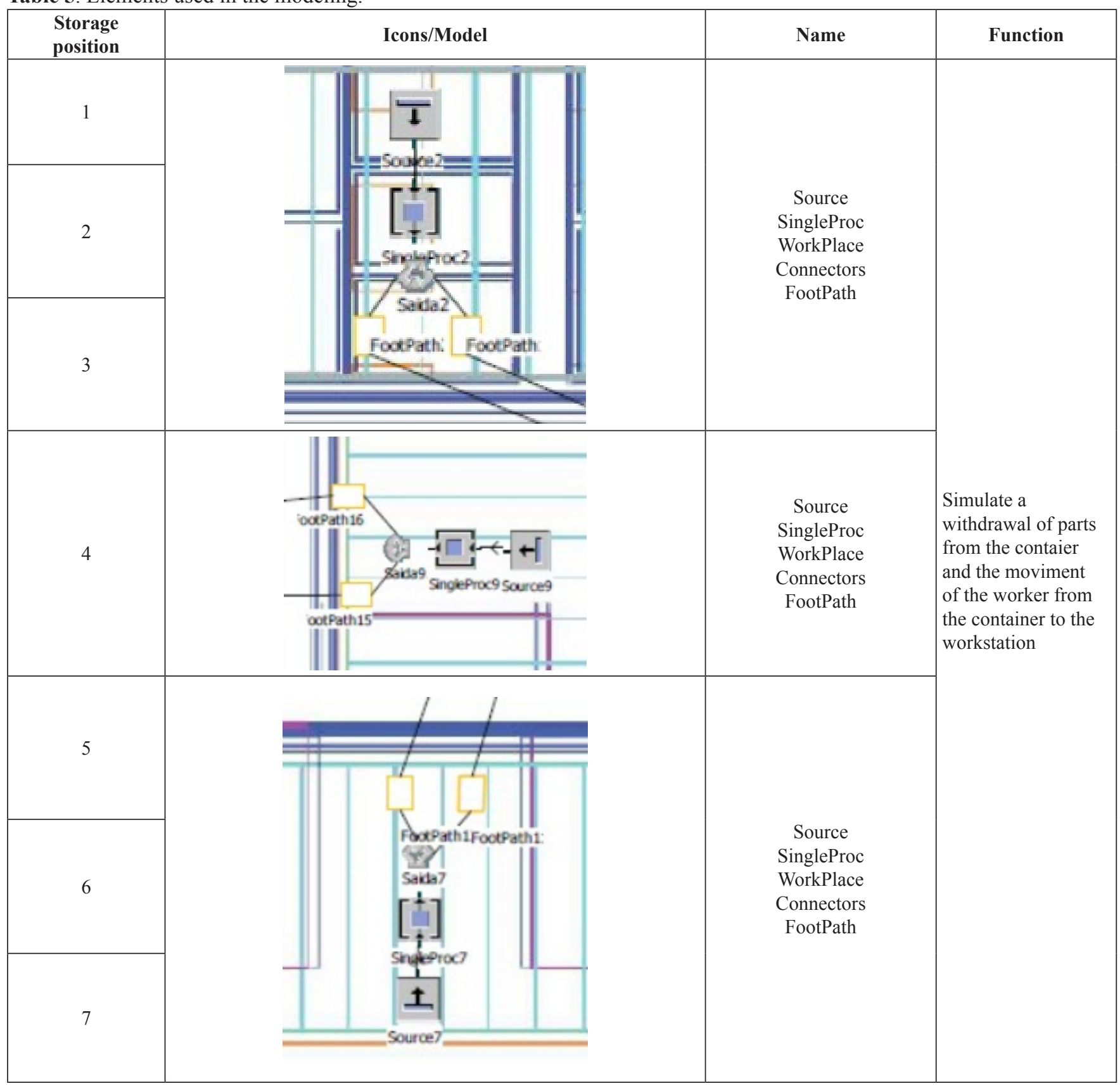


Table 5. Continued...

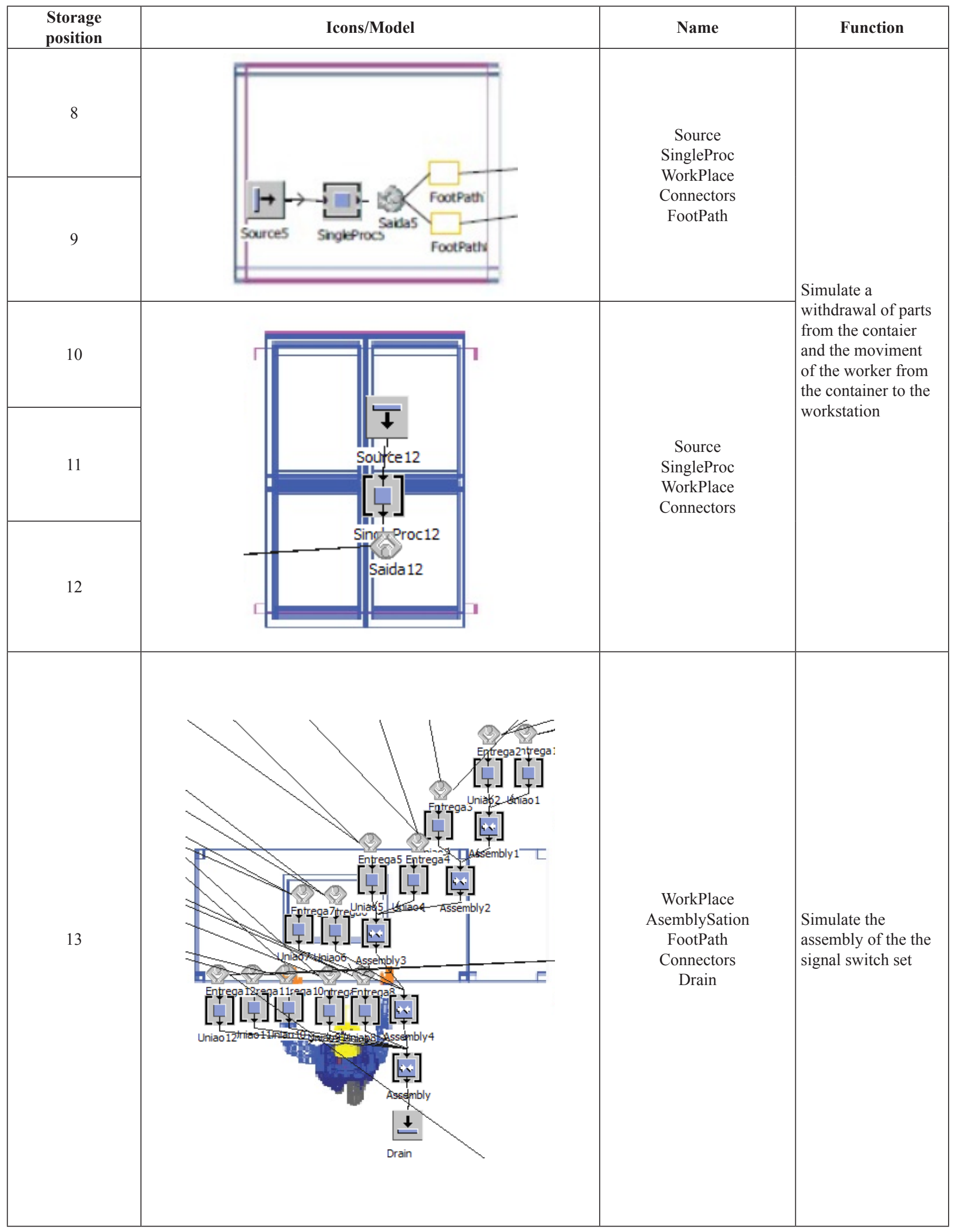


Table 6. Statistics concerning the assembly cell.

\begin{tabular}{|l|c|}
\hline \multicolumn{1}{|c|}{ Statistics } & Values \\
\hline Mean production value & 1 minute and 30 seconds \\
\hline Number of sets produced & 320 sets \\
\hline
\end{tabular}

Table 7. Statistics concerning the worker.

\begin{tabular}{|l|c|}
\hline \multicolumn{1}{|c|}{ Statistics } & Values \\
\hline Transportation time & 78 minutes and 20 seconds \\
\hline Assembly time & 401 minutes and 40 seconds \\
\hline Mean assembly time per set & 1 minute and 15 seconds \\
\hline Distance covered & $7850.40 \mathrm{~m}$ \\
\hline
\end{tabular}

According to the model about $83 \%$ of the worker's working time is intended for his main activity, the assembly of the signal switch set. The other $17 \%$ of his time refer to the transportation of parts for the workstation. These data to assess worker productivity in performing its main activity assembly. It can also be seen that during the 8 hours working journey the worker walked $7850 \mathrm{~m}$.

With de data from the model is possible to assess the distribution of the labor work throughout the working journey. The data is also a source of information for future optimization of the cell's layout to increase worker productivity and improve working conditions.

\section{Conclusions}

This work presented the application of a resource of Digital Factory (DF) in the study of man-machine interaction in an automotive manufacturing process. To this end, a theoretical background and a real case study based on a manufacturing cell in an automaker in Brazil were developed. The restrictions imposed to the model were adequate, and the results presented significant adherence to the expected values in a real case.

In an 8-hour shift, 320 turn signal switch sets were produced, a value close to the expected one. In addition, mean production time is 1 minute and 30 seconds, a value also in line with reality. The parameters concerning the worker are within expected magnitude, however mean assembly time per set was shown to be a little higher than what was expected: mean assembly time in a real cell is approximately 1 minute.

Analysis of operator's micromovements in the same manufacturing cell is recommended for future studies. Thus, the results can be compared with the content of this work, and new information can be identified. Such works contribute to the improvement of product development process and automotive manufacturing, and can also be used as parameters in new automotive engineering designs.

\section{Acknowledgements}

The authors thank CEA(Centro de Engenharia Automotiva) of the Escola Politécnica da Universidade de São Paulo for the support.

\section{References}

AMÉRICO, A.; ANTÓNIO, A. Factory templates for digital factories framework. Robotics and Computer-integrated Manufacturing, v. 27, n. 4, p. 755-771, 2011. http://dx.doi. org/10.1016/j.rcim.2011.02.004.

BRACHT, U.; GECKLER, D.; WENZEL, S. Digitale Fabrik. Methoden Und Praxisbeispiele. Berlin: Springer-Verlag, 2011. http://dx.doi.org/10.1007/978-3-540-88973-1.

BÜTTNER, K. Die digitale Fabrik entwickelt sich weiter in Richtung Industrie 4.0. (2014). Available at: http:// www.i40.de/die-digitale-fabrik-entwickelt-sich-weiter-inrichtung-industrie-4-0/. Acess at: 18 Nov. 2016.

CHERUBINI, A. et al. Collaborative manufacturing with physical human-robot interaction. Robotics and Computer-integrated Manufacturing, v. 40, p. 1-13, 2016. http://dx.doi.org/10.1016/j.rcim.2015.12.007.

CHOI, S. S.; KIM, B. H.; NOH, S. D. A diagnosis and evaluation method for strategic planning and systematic design of a virtual factory in smart manufacturing systems. International Journal of Precision Engineering and Manufacturing, v. 16, n. 6, p. 1107-1115, 2015. http:// dx.doi.org/10.1007/s12541-015-0143-9.

HARRISON, R.; VERA, D.; AHMAD, B. Engineering methods and tools for cyber-physical automation systems. Proceedings of the IEEE, v. 104, n. 5, p. 973-985, 2016. http://dx.doi.org/10.1109/JPROC.2015.2510665.

HUSÁR, J.; DUPLÁKOVÁ, D. Material flow planning for bearing production in Digital Factory. Key Engineering Materials, v. 669, n. 5, p. 541-550, 2016. http://dx.doi.org/10.4028/www.scientific.net/ KEM.669.541.

KIM, G. Y. et al. Digital factory wizard: an integrated system for concurrent digital engineering in product lifecycle management. International Journal of Computer Integrated Manufacturing, v. 23, p. 1028-1045, 2010. http://dx.doi.org/10.1080/0951192X.2010.511653.

KRÜCKHANS, B.; MEIER, H. Industrie 4.0 - Handlungsfelder der Digitalen Fabrik zur Optimierung der Ressourceneffizienz in der Produktion. Simulation in Produktion und Logistik, Entscheidungsunterstützung von der Planung bis zur Steuerung, p. 31-40, 2013. Available from: $<\mathrm{http}: / / \mathrm{www}$. asim-fachtagung-spl.de/asim2013/papers/Proof_102.pdf>. Acess in: 18 Nov. 2016.

KÜHN, W. Digital Factory - simulation enhancing the product and production engineering process. In: WINTER SIMULATION CONFERENCE, 2006, Piscataway, New Jersey. Proceedings... Canada: IEEE, 2006. p.1899-1906. http://dx.doi.org/10.1109/WSC.2006.322972.

MAROPOULOS, P. G. Digital enterprise technology-defining perspectives and research priorities. International Journal 
of Computer Integrated Manufacturing, v. 16, n. 7-8, p. 467-478, 2003. http://dx.doi.org/10.1080/0951192031 000115787.

OU, H.; ZOU, T. The application of digital factory in domestic chemical industry. In: CONTROL AND DECISION CONFERENCE (CCDC), 27., 2015, Chinese. Proceedings... Hoboken: IEEE, 2015. http://dx.doi. org/10.1109/CCDC.2015.7162686.

POLÁŠEK, P.; BUREŠ, M.; ŠIMON, M. Comparison of Digital Tools for ergonomics in practice. Procedia Engineering, v. 100, p. 1277-1285, 2015. http://dx.doi. org/10.1016/j.proeng.2015.01.494.

SIEMENS. Plant simulaton. Available from: https://www. plm.automation.siemens.com/pt_br/products/tecnomatix/ manufacturing-simulation/material-flow/plant-simulation. shtml. Access in: 18 Nov. 2016.

SILVA, G. C. Modelo de referência para o processo de desenvolvimento do produto automotivo e diretrizes para seleção de protótipos virtuais e físicos. Tese (Doutorado em Engenharia Mecânica de Projeto de Fabricação) - Escola
Politécnica. Universidade de São Paulo, São Paulo, 2013. http://dx.doi.org/10.11606/T.3.2013.tde-11032014-121333.

SILVA, G. C.; KAMINSKI, P. C. Application of digital factory concepts to optimize and integrate inventories in automotive pre-assembly areas. International Journal of Computer Integrated Manufacturing, v. 28, n. 6, p. 607-615, 2015. http://dx.doi.org/10.1080/0951192X.2014.881552.

SILVA, G. C.; KAMINSKI, P. C.; GRUBER, G. E. Usage of Digital Factory in the analysis of automotive production scenarios: available software and resources. Warrendale: SAE International, 2014. SAE Technical Paper Series. http:// dx.doi.org/10.4271/2014-36-0329.

TORO, C.; BARANDIARAN, I.; POSADA, J. A Perspective on Knowledge Based and Intelligent Systems Implementation in Industrie 4.0. Procedia Computer Science, v. 60, p. 362370, 2015. http://dx.doi.org/ 10.1016/j.procs.2015.08.143.

VEREIN DEUTSCHER INGENIEURE - VDI. VDI 4499. Blatt 1/Part 1: Digitale Fabrik Grundlagen. Düsseldorf: VDI, 2008. 52 p. 